Adv. Geosci., 48, 19-30, 2019

https://doi.org/10.5194/adgeo-48-19-2019

(C) Author(s) 2019. This work is distributed under

the Creative Commons Attribution 4.0 License.

Advances in

Geosciences

(c) (i)

\title{
Spatio Temporal Soil Moisture Dynamics and Runoff under Different Soil Cover Conditions in a Semiarid Representative Basin in Brazil
}

\author{
Abelardo A. A. Montenegro ${ }^{1}$, Iug Lopes ${ }^{1}$, Ailton A. de Carvalho ${ }^{1}$, João L. M. P. de Lima ${ }^{2}$, Thais E. M. S. de Souza ${ }^{3}$, \\ Helio L. Araújo ${ }^{1}$, Frederico A. C. Lins ${ }^{1}$, Thayná A. B. Almeida ${ }^{1}$, and Hugo G. L. A. Montenegro ${ }^{1}$ \\ ${ }^{1}$ Department of Agricultural Engineering, Federal Rural University of Pernambuco State, Recife, 52171-900, Brazil \\ ${ }^{2}$ MARE - Marine and Environmental Sciences Centre, Department of Civil Engineering, Faculty of Science and Technology \\ of the University de Coimbra, 3030-788 Coimbra, Portugal \\ ${ }^{3}$ Bioscience Department, Federal University of Pernambuco State, Recife, 50670-901, Brazil
}

Correspondence: Abelardo A. A. Montenegro (montenegro.ufrpe@gmail.com)

Received: 30 November 2018 - Revised: 2 April 2019 - Accepted: 13 May 2019 - Published: 5 June 2019

\begin{abstract}
Hydrological studies in small basins are essential for investigating the role of distinct processes on water resources conservation and to assess the impact of the natural ecosystems on improving water security especially in semiarid environments. In Brazil, the cooperative hydrological Network REHISA ("REde de HIdrologia do SemiÁrido") comprises hydrologists from several universities of Brazil, focusing on field measurements, monitoring and modeling activities in well instrumented experimental rural catchments located at different regions and biomes in Semiarid environment. Water scarcity is a common aspect among the catchments, as well as risks of soil and water degradation. The objective of this work is to present assessments of near surface soil moisture spatial-temporal distribution, and to evaluate the impact of soil conservation techniques in reducing runoff, using small-scale experimental plots in a representative catchment of the Pernambuco State, Brazil. The study catchment is located in Alto Ipanema River Basin (AIRB) (with an area of $150 \mathrm{~km}^{2}$ ), which is located at the semiarid region of the São Francisco River (area of $641000 \mathrm{~km}^{2}$ ). Soil and water monitoring was performed in experimental plots with different soil cover conditions (Bare soil plots; Plots with natural cover - Caatinga Biome vegetation; Plots with cactus Palma barriers; and Plots with mulch cover Dry grass mulch at $4 \mathrm{tha}^{-1}$ ), where probes were installed for high resolution soil moisture assessment. In addition, regular soil moisture monitoring campaigns were conducted at 7 different locations, using a capacitance probe, with arboreal and shrub Caatinga vegetation, pasture and bare soil, pre-
\end{abstract}

dominantly Brachiaria decumbens. Mulch cover runs close to the Caatinga cover, but still with higher runoff generation, and presenting lower soil moisture temporal mean values. Caatinga was highly effective in terms of soil and water conservation at the small basin scale for both the dry and the wet season, resulting in a positive nexus between vegetation and water availability at the region.

\section{Introduction}

Near-surface soil moisture plays an important role on ecohydrological processes, influencing the partitioning of precipitation into infiltration and runoff, and also controlling evapotranspiration (Grayson et al., 1997). Thus, a better understanding of the spatio-temporal distribution of soil moisture is crucial for several applications, including soil conservation, environmental protection and rainfed agriculture.

Field hydrological studies in small basins allow investigation of the relative role of distinct processes on soil and water resources conservation (McClain, 2013), and also the impact assessment of agricultural conservation practices on water security and soil protection, especially in semiarid environments.

According to Maneta et al. (2008), the discontinuity of the processes in semiarid areas both in space and in time produces a highly complex discontinuous nonlinear rainfallrunoff relationship, interfering also on infiltration and lat- 
Table 1. Physical characteristics of the Argisol at the experimental sites. Source: Santos et al. (2010).

\begin{tabular}{|c|c|c|c|c|c|c|c|}
\hline \multirow{2}{*}{$\begin{array}{l}\text { Layer } \\
\mathrm{cm}\end{array}$} & \multirow[t]{2}{*}{ Horizon } & Sand & Clay & Silt & \multirow{2}{*}{$\begin{array}{r}\mathrm{Cdw}^{1} \\
\%\end{array}$} & $\mathrm{Pd}^{2}$ & $\mathrm{Sd}^{3}$ \\
\hline & & & $\%$ & & & \multicolumn{2}{|c|}{$\mathrm{kg} \mathrm{dm}^{-3}$} \\
\hline $0-12$ & Ap & 44.85 & 23.15 & 32.00 & 11.20 & 2.64 & 1.48 \\
\hline $13-27$ & A1 & 44.19 & 26.48 & 29.33 & 11.20 & 2.72 & 1.51 \\
\hline $27-46$ & A2 & 31.52 & 32.48 & 36.00 & 15.20 & 2.64 & 1.45 \\
\hline $46-69$ & $\mathrm{AB}$ & 28.86 & 33.81 & 37.33 & 15.20 & 2.67 & 1.68 \\
\hline $69-86$ & $\mathrm{Bt}$ & 13.37 & 60.83 & 25.80 & 32.87 & 2.66 & 1.70 \\
\hline
\end{tabular}

${ }^{1} \mathrm{Cdw}$ : Clay-dispersed in water. ${ }^{2} \mathrm{Pd}$ : Particle density. ${ }^{3} \mathrm{Sd}$ : Soil density.

eral flows, and then on vegetation development. In small ephemeral semiarid basins, soil moisture is the most relevant state variable, controlling the internal water distribution, and water resources availability.

Montenegro et al. (2018) highlighted the importance of soil moisture dynamics on the ecological functioning of a volcanic archipelago at the Brazilian coast, and the impact of rainfall temporal regime on infiltration and on soil moisture temporal variability.

Due to the limited rainfall depth available, usually concentrated within 3-4 months $\mathrm{yr}^{-1}$, and the high evaporative demand, water deficit is a challenge in the Brazilian semiarid region, impacting ecosystem services, crop production and limiting livestock (Mutti et al., 2019; Lopes et al., 2019). Natural vegetation development is also limited, comprising xerophytes species, dominating the Caatinga Biome, which is a deciduous dry forest biome and scrub vegetation, typical of the Brazilian semiarid region.

In general, the natural vegetation provides environmental services for the ecosystem at high levels, but not food production (Foley et al., 2005). Hence, land use strategies such as cropland with restored ecosystem services are required for sustainable development.

Interception processes through natural vegetation, even for sparse rangeland vegetation of semiarid areas, is a key factor for kinetic energy reduction of rainfall, attenuating soil losses, runoff, and inducing infiltration. Moreover, natural barriers along hillslopes control overland flow, inducing sedimentation of soil particles transported by natural discharges. In semiarid areas, after rainfall interception, stem flow even in a deciduous vegetation with limited canopy cover can play a key role for soil moisture replenishment, enhancing infiltration and reducing hydrograph peaks. According to Brasil et al. (2017), stem flow can be associated to two roughness coefficients, one linked to large scale characteristic of the Caatinga Biome, and another coefficient related to the plant leaves morphology.

The influence of natural barriers on overland flow have been verified by dos Santos et al. (2010) and de Borges et al. (2014), from field monitoring campaigns in experimental basin of Pernambuco State, as part of the objectives stated by the Brazilian semiarid cooperative hydrological Network
REHISA ("REde de HIdrologia do SemiÁrido"). The network comprises investigations focusing on field measurements, monitoring and modeling activities in well instrumented experimental rural catchments. Seven experimental basins have been instrumented at the Brazilian northeast, focusing on rainfall- runoff processes and soil moisture dynamics.

Water scarcity is a common aspect among the catchments along Pernambuco State semiarid region, as well as the environmental degradation risks, particularly erosion and salinization, representing a challenge to social and economic development (de Londe et al., 2014). Rural activities in the region are mainly carried out by small farm holders. Although extreme poverty decreased significantly in Brazil in recent years, Northeast rural areas continue to exhibit the highest poverty scenarios in the country (Santos et al., 2015), thus urgently requiring public policies to promote sustainable agricultural production, food security and also protection of the natural resources (Schneider et al., 2010). A great part of seasonally dry tropical forests (set in semiarid regions, with temperatures above $17^{\circ} \mathrm{C}$ and high evapotranspiration rates) located mostly in North Argentina and Northeast of Brazil, are being (or already are) degraded in different ways for the purpose of agricultural and livestock production (Stuhler and Orrock, 2016).

Nature-based solution is a concept increasingly adopted around the world, focusing on participatory actions to protect, manage or restore natural or modified ecosystems, enhancing food protection and biodiversity (WWAP, 2018). In this study, two low cost nature-based solutions are analysed: mulching cover and cactus barriers. Dry matter mulching has been largely studied in literature for erosion control, runoff reduction and soil moisture maintenance in hillslopes. Mulching promotes the reduction of surface runoff and traps sediments, hence enhancing water retention and infiltration.

Montenegro et al. (2013) and Lopes and Montenegro (2017) investigated the impact of two densities of straw mulch on reducing soil losses and increasing soil moisture, under simulated rainfall. Mulching performance in protecting soil surface from erosion has also been verified by e.g. Abrantes et al. (2018) and Prats et al. (2017), using mulch cover from natural vegetation. Adopting field plots in the Brazilian semiarid, dos Santos et al. (2010) and dos Borges et al. (2014) observed significant increase in rainfed crop production in sloped areas for beans and maize using mulching.

On the other hand, vegetative barriers forming narrow strips across the dominant slope can reduce soil loss, inducing deposition of eroded sediment. Such alternative was also studied by Santos et al. (2010) and Borges et al. (2014), adopting Opuntia ficus-indica (L.) Mill Cactus as a way to slow down runoff and increase soil moisture, in the Pernambuco State semiarid.

Spineless cactus forage is an important alternative for farmers in the Brazilian semiarid, presenting high productivity potential, high water use efficiency and tolerance to 


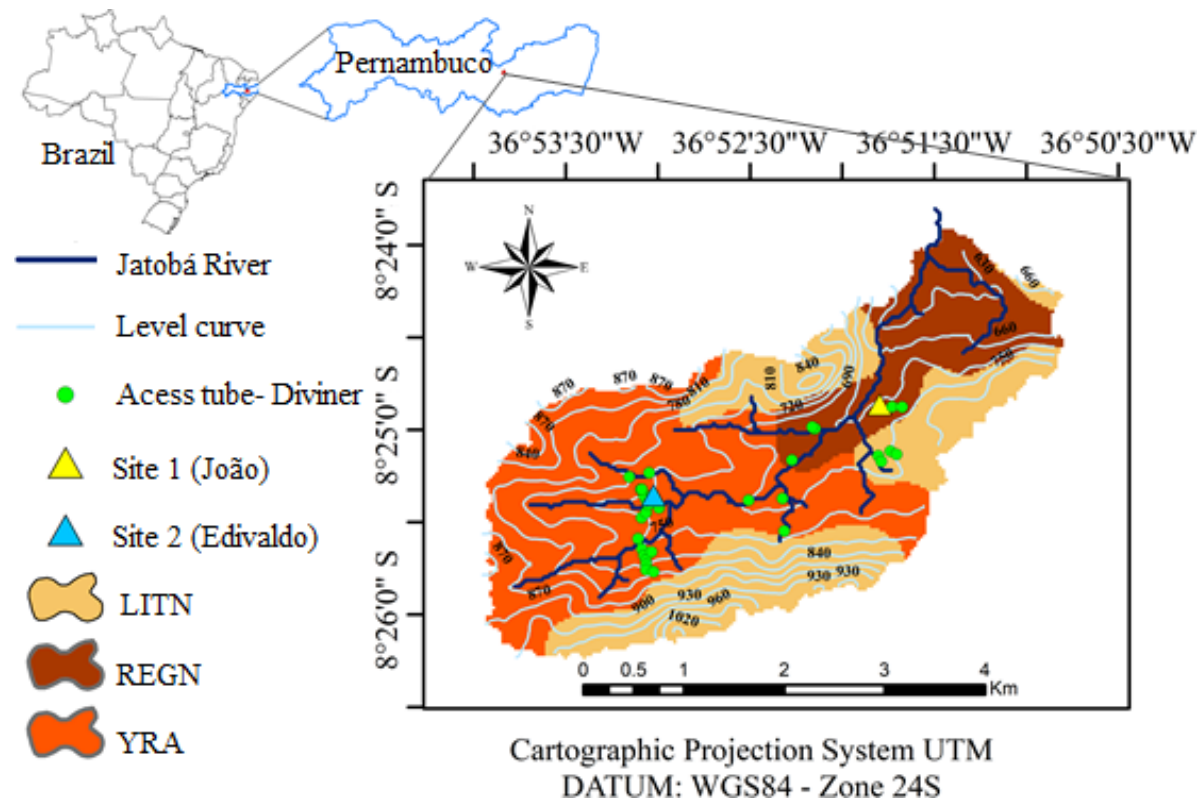

Figure 1. Location of the Jatobá Experimental Basin, Pernambuco State, Brazil, showing the main soil types, location of access tubes for soil moisture monitoring, and view of the typical open arboreal - shrubby Caatinga vegetation, with a view of an access tube. LITN: Litholic Neosol; REGN: Regolitic Neosol; YRA: Yellow Red Argisol.
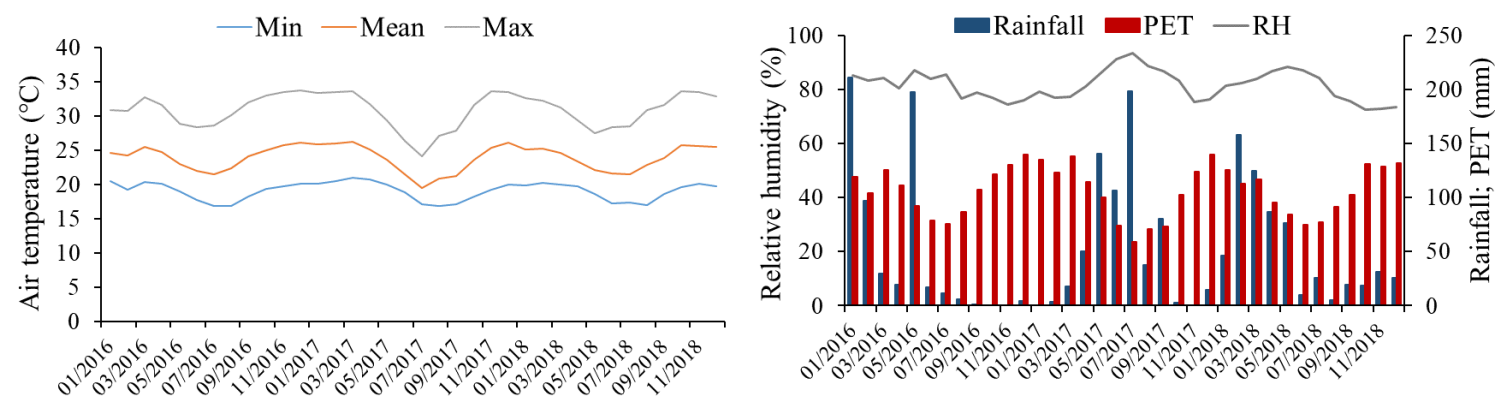

Figure 2. Time series for air temperature, monthly rainfall and potential evapotranspiration (PET), and relative humidity. Jatobá Basin, Pesqueira-PE, Brazil.

water stress (Dubeux et al., 2006). Cactus are largely grown in the Brazilian semiarid, and the two main species are Opuntia ficus-indica and Nopaleacochenillifera. In Pernambuco State, the main cultivated cactus forage clones are the "Orelha de Elefante Mexicana", which belongs to the Opuntia genus, and "Miúda" and "IPA Sertânia" of genus Nopalea (Barbosa et al., 2018). The shape and morphological architecture of spineless cactus canopy, with cladodes varying in size from 0.30 to $0.50 \mathrm{~m}$ in height and 0.20 to $0.30 \mathrm{~m}$ in width affect their photosynthetic capacity (Silva et al., 2015), and also might constitute promising vegetative barriers, slowing and ponding runoff in sloped areas, hence controlling soil erosion.

The objective of this work is to present field assessments of near surface soil moisture spatio-temporal distribution, and to evaluate the impact of naturally based soil conservation techniques in reducing runoff, compared to natural Caatinga cover condition, using small scale runoff plots and a network of access tubes for soil moisture monitoring in an experimental ephemeral basin of the Pernambuco State, Brazil.

\section{Study area and methodology}

The study area is the Jatobá Experimental Basin (with an area of $14 \mathrm{~km}^{2}$ ), located at the Alto Ipanema River Basin (AIRB) (with an area of $150 \mathrm{~km}^{2}$ ), in the State in Pernambuco, in the Brazilian semi-arid region (Fig. 1). The Ipanema catchment is part of the São Francisco River basin (area of $641000 \mathrm{~km}^{2}$ ) and is located in the Brazilian drought polygon (Montenegro and Ragab, 2010). In this polygon, there is already a conflict among water users, and the region is vulnerable to droughts (Krol et al., 2006). 
Table 2. Physical characteristics of the soil profile for the different locations of Diviner $-2000^{\circledR}$ access tubes. Caatinga land cover.

\begin{tabular}{|c|c|c|c|c|c|c|}
\hline \multirow[t]{2}{*}{ Point/Cover/Soil Class } & \multirow[t]{2}{*}{ Elevation (m) } & \multirow[t]{2}{*}{ Layer (m) } & \multirow[t]{2}{*}{ Osat $\left(\mathrm{m}^{3} \mathrm{~m}^{-3}\right)$} & Sand & Clay & Silt \\
\hline & & & & \multicolumn{3}{|c|}{$\mathrm{g} \mathrm{kg}^{-1}$} \\
\hline \multirow[t]{4}{*}{ P03/CA/YRA } & \multirow[t]{4}{*}{765.9} & $0-0.10$ & 0.51 & \multirow{2}{*}{708.0} & \multirow{2}{*}{172.0} & \multirow{2}{*}{120.0} \\
\hline & & $0.10-0.20$ & 0.43 & & & \\
\hline & & $\begin{array}{l}0.20-0.30 \\
0.30-0.40\end{array}$ & 0.42 & \multirow{2}{*}{608.0} & \multirow{2}{*}{232.0} & \multirow{2}{*}{160.0} \\
\hline & & $0.50-0.40$ & & & & \\
\hline \multirow{4}{*}{ P30/CA/REGN } & \multirow{4}{*}{752.1} & $0-0.10$ & 0.42 & \multirow{2}{*}{724.0} & \multirow{2}{*}{116.0} & \multirow{2}{*}{160.0} \\
\hline & & $0.10-0.20$ & 0.40 & & & \\
\hline & & $0.20-0.30$ & 0.42 & \multirow{2}{*}{814.0} & \multirow{2}{*}{82.4} & \multirow{2}{*}{103.6} \\
\hline & & $0.30-0.40$ & 0.38 & & & \\
\hline \multirow{4}{*}{ P36/CA/YRA } & \multirow{4}{*}{756.8} & $0-0.10$ & 0.37 & \multirow{2}{*}{623.2} & \multirow{2}{*}{182.0} & \multirow{2}{*}{194.8} \\
\hline & & $0.10-0.20$ & 0.37 & & & \\
\hline & & $0.20-0.30$ & 0.38 & & & \\
\hline & & $0.30-0.40$ & 0.38 & 504.8 & $2 / 2.0$ & 223.2 \\
\hline \multirow{4}{*}{ P43/CA/YRA } & \multirow{4}{*}{773.5} & $0-0.10$ & 0.44 & \multirow{2}{*}{648.0} & & \\
\hline & & $0.10-0.20$ & 0.43 & & $21 / .6$ & 134.4 \\
\hline & & $0.20-0.30$ & 0.45 & 6080 & 2520 & 1400 \\
\hline & & $0.30-0.40$ & 0.43 & 000.0 & $2 J 2.0$ & 140.0 \\
\hline & 7597 & $0-0.10$ & 0.43 & 5608 & 2120 & 2182 \\
\hline P4J/CA/YRA & 159.1 & $0.10-0.20$ & 0.42 & 569.8 & 212.0 & 218.2 \\
\hline & & $0.20-0.30$ & 0.41 & & & \\
\hline & & $0.30-0.40$ & 0.40 & 558.4 & 252.0 & 189.6 \\
\hline $\mathrm{P} 46 / \mathrm{CA} / \mathrm{YRA}$ & 7557 & $0-0.10$ & 0.45 & 7080 & 2176 & 74.4 \\
\hline P $40 / C A / Y K A$ & 150.1 & $0.10-0.20$ & 0.45 & 100.0 & 217.0 & \\
\hline & & $0.20-0.30$ & 0.46 & & & \\
\hline & & $0.30-0.40$ & 0.45 & 648.0 & 212.0 & 218.2 \\
\hline P50/CA/YRA & 779.8 & $0-0.10$ & 0.38 & & 292.0 & 212.2 \\
\hline PJU/CA/YRA & $1 / 9.8$ & $0.10-0.20$ & 0.39 & 495.8 & 292.0 & 212.2 \\
\hline & & $0.20-0.30$ & 0.38 & 4362 & 3920 & 1718 \\
\hline & & $0.30-0.40$ & 0.39 & 430.2 & 392.0 & $1 / 1.8$ \\
\hline & & $0-0.10$ & 0.44 & 728.0 & & 120.0 \\
\hline P5I/CA/YRA & 731.6 & $0.10-0.20$ & 0.42 & 128.0 & 152.0 & 120.0 \\
\hline & & $0.20-0.30$ & 0.46 & 7080 & & \\
\hline & & $0.30-0.40$ & 0.39 & 708.0 & 197.6 & 94.4 \\
\hline
\end{tabular}

CA - Caatinga; YRA - Yellow Red Argisol; REGN - Regolitic Neosol.

The climate in the region is extremely hot semiarid Steppe Type, according to the Köppen classification, with a mean annual rainfall of $600 \mathrm{~mm}$ (normally concentrated between the months of April and July, but it can change from one year to another) and an average temperature of $23^{\circ} \mathrm{C}$, and potential evapotranspiration of approximately $2000 \mathrm{~mm}$ a year (Melo and Montenegro, 2015). Lopes et al. (2018) studied the spatial distribution of rainfall for region, and also observed low rainfall availability conditions for the whole area in the same period.

Figure 2 presents air temperature characteristics, rainfall distribution for the experimental period, potential evapotranspiration (PET), and relative humidity. Total rainfall (and PET) for 2016, 2017 and 2018 were 593 (1292 mm), 651
$(1253 \mathrm{~mm})$, and $628 \mathrm{~mm}(1637 \mathrm{~mm})$, respectively. Montenegro and Ragab (2010) verified that the mean total rainfall for the base line period from 1961-1999 was $702 \mathrm{~mm}$, while for the 2002 to 2007 period was $750 \mathrm{~mm}$. In addition, mean value for PET was equal to $1086 \mathrm{~mm}$. Hence, the experimental period adopted in this study can be considered representative for the region.

Vegetation is predominantly hyperxerophytic Caatinga (Montenegro and Montenegro, 2006), varying from arboreal closed Caatinga to open shrub Caatinga (Montenegro and Ragab, 2010).

The vegetation presents strong seasonality over time, characteristic of the Caatinga Biome. In the dry period, the native forest area losses foliage (deciduous behaviour). At regions 

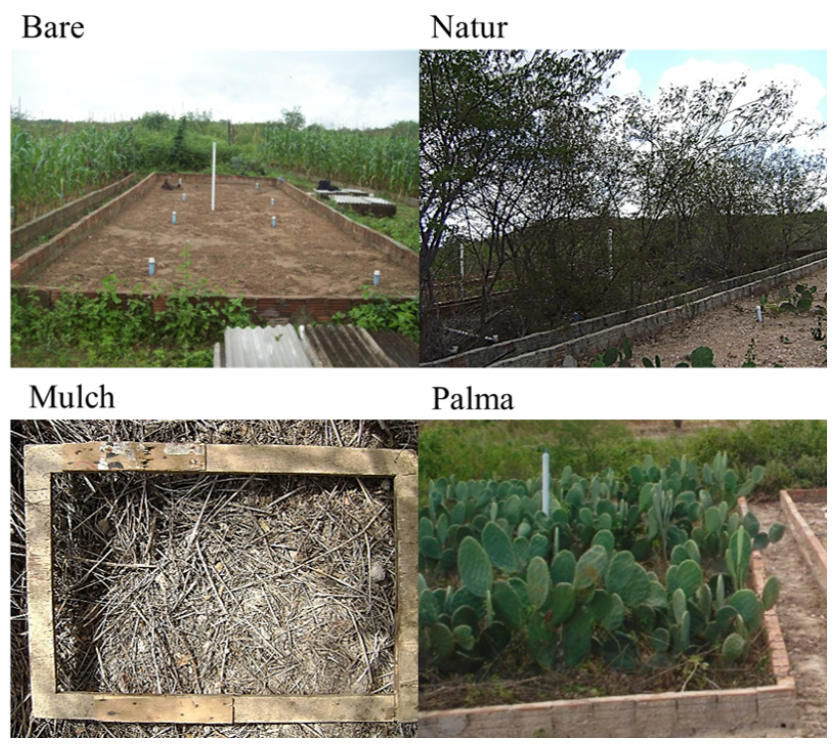

Figure 3. Photographs of the adopted soil cover treatments: bare soil; mulch cover; cactus barriers, and Natural Caatinga cover.

with sparse vegetation, large areas exhibit bare soils. The cover condition changes considerably during the rainy season, which is a characteristic of the semi-arid region, with a fast foliage regeneration (Santos et al., 2016).

Climatic data were recorded at an Automatic Weather Station (Campbell Scientific ${ }^{\circledR}$ ) installed nearby the experimental area, as observed in the map (Fig. 1). The station consists of a set of sensors and a communication interface for data recording (CR1000 datalogger) and transfer, including: an anemometer, a rain gauge, a temperature sensor and relative humidity of the air and a pyranometer, recording data hourly. Rainfall depths and temporal characteristics were measured by three automatic rain gauge (TB4-L, Campbell Scientific ${ }^{\circledR}$ ), connected to CR1000 dataloggers, which were programmed to record events every $5 \mathrm{~min}$.

Eight experimental plots $4.5 \mathrm{~m}$ wide and $11.0 \mathrm{~m}$ long were randomly estabilished at the hillslopes in the experimental basin, with a $5 \%$ slope, to investigate the performance of conservation practices for controlling soil moisture, runoff and erosion. The plots were grouped in two sites (named "João" and "Edivaldo"), each site comprising four plots, with the following soil cover treatments: bare soil, natural vegetation (Caatinga) cover, mulch cover, and Palma Cactus forming contour ridges. Table 1 presents the soil mean characteristics, classified as abruptic eutrophic Yellow Argisol (EMBRAPA, 1997). Mean soil moisture at field capacity is $0.16 \mathrm{~m}^{3} \mathrm{~m}^{-3}$ (dos Santos et al., 2010), and wilting point is equal to 0.05 (Montenegro and Ragab, 2010). Based on soil density in Table 1, soil total porosity is 0.40 .

Figure 3 shows a general view of the investigated cover conditions (Bare, Natur, Mulch and Palma): Bare - soil without any of natural or artificial cover on the plot; Natur - pre- dominant natural and/or spontaneous vegetation composed of small and medium - sized open caatinga, with predominant Quince (Croton sonderianus) and Jurema - Preta (Mimosa hostilis Benth.); Mulch - dry grass mulch (Brachiaria decumbens) with density of $8 \mathrm{tha}^{-1}$; Palma - presence of forage spineless palma (Opuntia cochenillifera) planted in regular spacing of $0.1 \times 1.5 \mathrm{~m}$, forming a vegetation contour ridge.

CS616 Campbell Scientific probes (one per plot) and access tubes for Neutrons Probe (one per plot) and Diviner Probe (also one per plot) were installed (Figs. 2 and 3), the former at $0.20 \mathrm{~m}$ depth, and the access tubes up to $0.60 \mathrm{~m}$, depending on the depth of the impediment layer.

Runoff and sediment yield were monitored and characterized at the 8 experimental plots. Experimental plots have been already established some years ago and are delimited by brick walls of $0.25 \mathrm{~m}$ height and inserted to $0.10 \mathrm{~m}$ into the soil. Downstream of the plot a drain collects runoff in two consecutive tanks of $1 \mathrm{~m}^{3}$. During the study period, no runoff events reached the maximum storage capacity of the collection tanks, nor significant losses of the stored water due to evaporation observed.

For extreme rainfall events in the 2016 to 2017 period, runoff and sediments were collected individually at the tanks, manually, within one day after each event.

At collection, the stored water at the two tanks was shaken for uniformity and samples were taken in $1 \mathrm{~L}$ triplicates. In order to estimate the sediment concentration, samples were dried in an oven $\left(105^{\circ} \mathrm{C}\right)$.

In addition to the aforementioned sites, regular soil moisture monitoring campaigns have been conducted at 25 different locations randomly distributed in the experimental basin (as already shown in Fig. 1), using a capacitance probe (Diviner $\left.-2000^{\circledR}\right)$, with different land use, vegetation cover, and topographic elevation. Access tubes were installed up to $0.60 \mathrm{~m}$ depth. However, in this work, soil moisture data were used for 7 distributed sites in the upper part of the basin, along a transect, where the predominant soil class is Yellow Red Argisol and the cover is the Caatinga. In Table 2, it is shown the physical characteristics for the $0-0.40 \mathrm{~m}$ soil profile. Measurements at the access tubes located at the chosen transect properly represent the mean behaviour of soil moisture in the basin, as verified by Silva Júnior et al. (2016), using the temporal stability methodology (Vachaud et al., 1985).

Soil moisture at the access tubes was measured monthly, except during the rainy season, when readings were taken twice a month.

\section{Results and discussions}

Soil moisture time series for the period from 2016 to 2018 at the experimental plots are presented in Fig. 4a, for the soil layer of $0-0.20 \mathrm{~m}$, and also the recorded daily rainfall. 

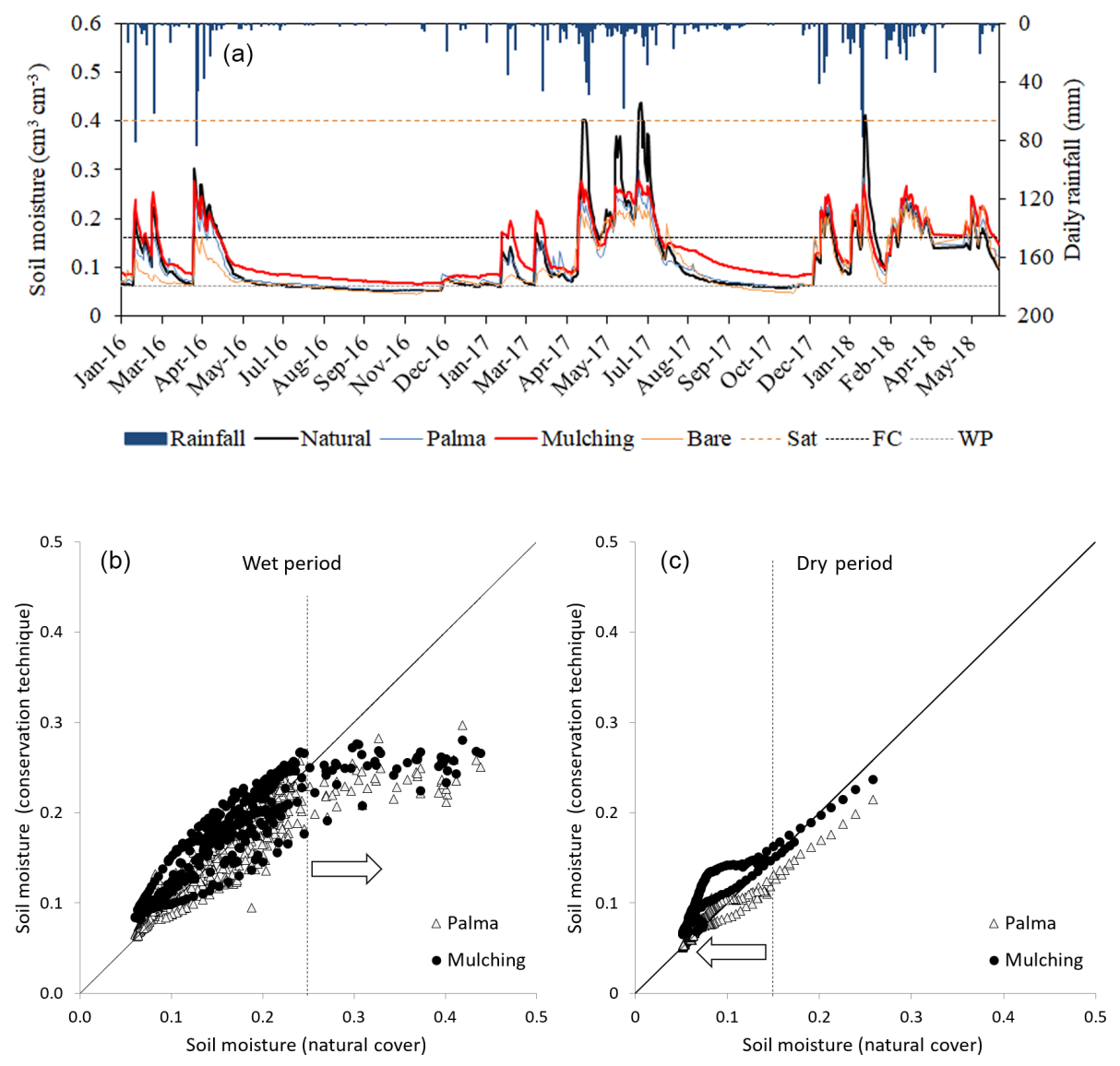

Figure 4. Time series for soil moisture, for native vegetation (Caatinga), Cactus barriers (Palma), mulching and bare soil, at the experimental plots, at site 1 (João), for the 0-0.20 m layer (a); Comparison of soil moisture for different cover conditions with Caatinga (b, c). Sat: Saturated soil moisture; FC: Field Capacity; WP: Wilting Point.

The study plots under natural cover (Caatinga biome) presented the highest near surface soil moisture contents for wet days, after high rainfall depths, mainly by the end of the wet season, due to canopy development. For the dry period, mulching treatment exhibited the highest soil moisture contents. Cactus barriers and mulching cover showed promising results, contributing to the reduction of runoff and increasing the infiltration processes. The bare soil plots, used to represent land degraded sites due to deforestation, exhibited the lowest values of soil moisture and the highest values for runoff and soil loss. Results for bare soil treatments are associated to observed soil crusting at the surface, forming a thin layer which reduces hydraulic conductivity, and hence infiltration. Figure $4 \mathrm{~b}$ and $\mathrm{c}$ present the comparison of soil moisture for the Caatinga natural cover and conservation treatments, for both wet and dry seasons. In spite of the experimental period of only 2 years, it can be verified from data that Caatinga cover efficiently contributes for the highest soil moistures, for the wet condition (particularly for soil moisture values higher than 0.25 ) due to infiltration, while mulching is effective in maintaining higher soil moisture for dry soil scenarios, for soil moisture values lower than 0.15 , approximately the field capacity soil moisture.

As shown in Fig. 4b, soil moisture at plots with conservation practices is lower than at plots with natural cover, due to canopy role for rainfall interception. In Fig. 4b, soil moisture content of 0.25 is a threshold value from which soil water storage at Caatinga plots is higher than soil water at plots with conservation practices. At the studied semiarid catchment, soil moisture is higher than the aforementioned threshold value, favouring canopy development, stemflow, and decreasing relative throughfall, which contributes to a higher infiltration depth. On the other hand, during the dry season, soil moisture for the Caatinga plots is lower than at plots with conservation practices, for contents below 0.15 , as shown in Fig. 4c. Such behavior is associated mainly to evapotranspiration dynamics, highlighting the role of the $8 \mathrm{tha}^{-1}$ mulch cover in controlling water losses from soil surface.

Hence, mulch and Cactus barriers were both suitable conservation practices in increasing soil moisture in the experimental plots, mainly for the dry season.

It was verified that the sites with Caatinga Natural Cover presented the highest coefficient of variation for soil mois- 


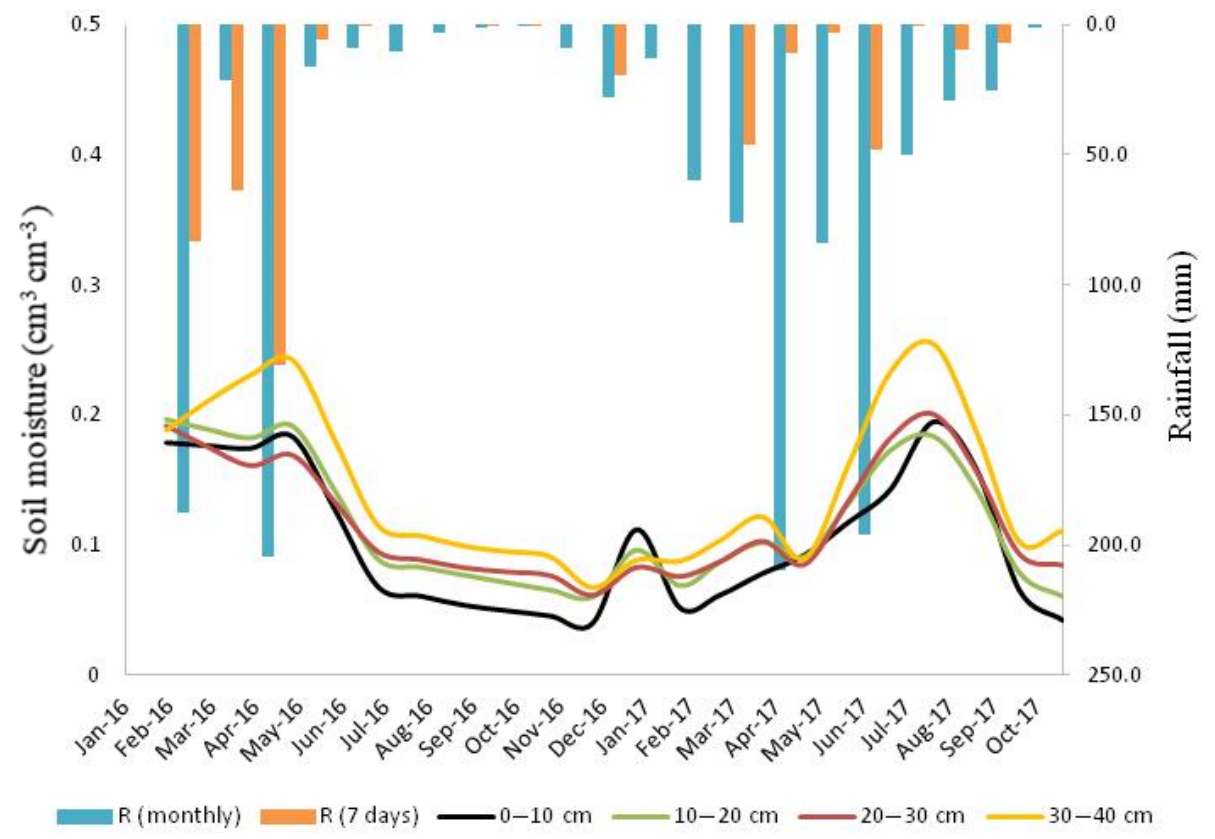

Figure 5. Mean soil moisture for different layers along soil profile, measured using the Diviner Probe, for sites with the same vegetation cover (Caatinga).

ture, due to infiltration and, on the other hand, root water uptake.

Moreover, it should be highlighted that in Caatinga areas, higher water contents are verified at deeper layers, which have a relevant role in sustaining crop evapotranspiration and natural biomass production in the semiarid basin.

In studies of water and soil conservation in watersheds in Africa, Wenninger et al. (2008) highlighted that hydrological processes in semi-arid regions usually present high spatio-temporal variability. Hence, rainfall and runoff measurements are essential for soil moisture dynamics investigation, in order to properly understand runoff generation and mitigate soil erosion. Brazilian Northeast, particularly the semi-arid of Pernambuco State, is usually subject to high intensity local rainfall events, known as thunderstorms (Santos et al., 2016). Such events cause high runoff rates and sediment losses, requiring conservation alternatives to be adopted, to prevent irreversible damages to the topsoil.

Mulch and Cactus barriers also exhibited higher soil moisture peaks than bare soil treatment. For 2017 rainy season, Caatinga vegetation response was significantly higher, which is associated to a more pronounced canopy development. The year 2016 came after a five years drought period, which ended in 2015, causing severe impact to crop production and vegetation leaf development.

Soil moisture spatio-temporal variability in Natural Caatinga cover, using mean values from sites with the same vegetation cover (Caatinga shrub natural vegetation) is shown in the Fig. 5. When analysing soil moisture spatial distribution along the experimental transect, high variabil- ity is observed. Moreover, it can be verified in Fig. 5 that in Caatinga areas, higher water contents are verified at deeper layers. Such result contributes to a higher root water uptake, enhancing crop evapotranspiration and natural biomass production. Figure 5 also exhibits the monthly rainfall and the seven days cumulative antecedent rainfall prior to each monitoring campaign.

Figure 6 presents the mean soil moisture for each monitored soil layer, and also the interval of one standard deviation around the mean value, representing the spatial variability of soil moisture among sites. It can be verified that the standard deviation increases with depth, and hence the spatial variability. Grayson et al. (1997) highlighted that in semiarid basins hydrological processes are more fragmented in space. Spatial variability is higher where lower lateral flows occur, and vertical water fluxes dominate.

It can be observed that at dry periods, there is a time lag between the first rainfall events and the soil moisture response, mainly at the deeper soil layers, due to limited hydraulic conductivity. Menezes et al. (2013), evaluating the soil moisture dynamics at the top soil layer, at the same basin, verified distinct rainfall-soil moisture dynamics at areas with Caatinga cover and bare soil, especially at the beginning of the rainy season. Additionally, the authors observed higher soil water contents in areas where Caatinga is present, compared to bare soil regions. Such results are consistent with those obtained by Silva Júnior et al. (2016), evaluating near surface soil moisture temporal stability (from 0 to 0.10 and from 0 to $0.20 \mathrm{~m}$ ), comparing sites with pasture cover, bare soils and Caatinga Natural cover in the Jatobá Experimental Basin, 

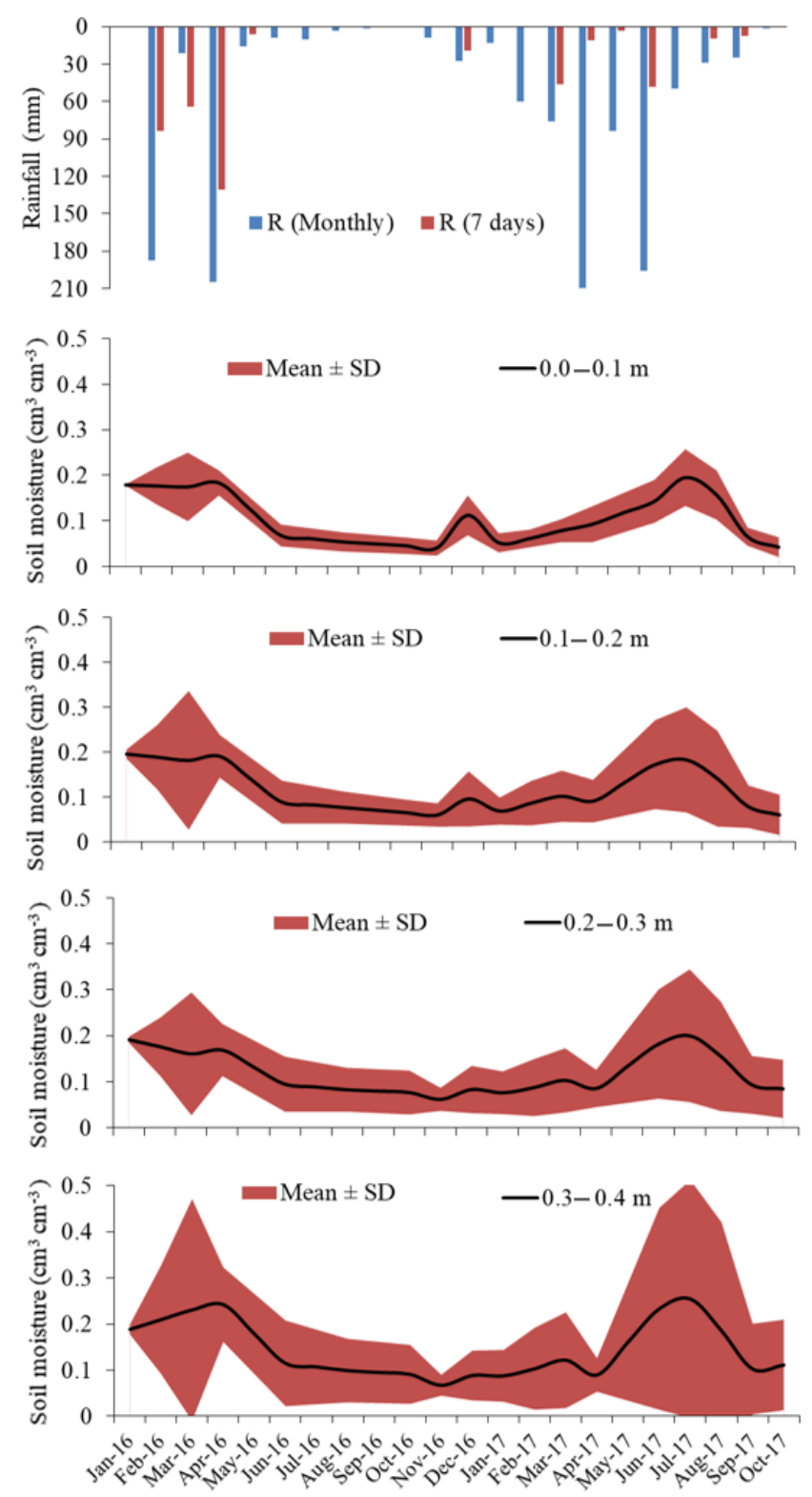

Figure 6. Time series for the mean soil moisture, for native vegetation (Caatinga), for the $0-0.10,0.10-20,0.20-0.30,0.30-0.40 \mathrm{~m}$ layers. It is also presented the one standard deviation interval around the mean value.

throughout rainy and dry seasons, between 2010 and 2014, also using a Diviner $-2000^{\circledR}$ capacitance probe.

Figure 7 presents the mean soil moisture for the whole 0 $0.40 \mathrm{~m}$ layer, for all sites located at areas with Caatinga vegetation, and the one standard deviation interval around the mean. Coefficients of variation are also presented, as well as the net vertical component (R-PET). Larger one deviation intervals are verified at the beginning of the rainy periods, as a result of rainfall variability, soil and vegetation heterogeneity, and topographic control. As the soil profile becomes wetter, lateral flow increases, also increasing the spatial correlation among different sites, as pointed out by Grayson et al. (1997), then reducing spatial variability. When the soil dries, lateral flows are reduced, and the coefficient of variation increases as the evapotranspiration exceeds rainfall. It can be clearly observed that a seasonal variation occurred between 2016 and 2017.

In spite of the monthly time scale for soil moisture monitoring at the experimental transect at the head of the basin, general spatial behaviour for different soil layers can be observed. The temporal variation of the standard deviation and coefficient of variation can be related to monthly rainfall and monthly values for R-PET.

Mulch and Cactus barriers were both effective treatments in reducing runoff and soil loss in the experimental plots, as shown in Figs. 8 and 9. By far, bare soil condition is associated to the highest runoff depths. According to Fig. 8, for mulching treatment, runoff values are close to natural vegetation plots (Caatinga), although presenting higher standard deviations. Such results are consistent with the soil moisture temporal observation from the near surface CS616 Probes (already shown in Fig. 4).

Silva Júnior et al. (2016) also monitored the same experimental basin, and observed that areas with Caatinga cover presented higher soil moisture than bare soil or pasture regions. Moreover, de Borges et al. (2014) and Carvalho et al. (2019) verified that mulching significantly increased soil moisture, highlighting the potential of such technique in increasing soil water availability in the semiarid.

Figure 9 also compares runoff and soil loss of different cover conditions with Caatinga. It can be observed that runoff generated at the mulching cover plot is close to the $1: 1$ line, reinforcing the similar behaviour of such treatment when compared to the natural vegetation. Rainfall- runoff and rainfall- soil loss relationships present both an exponential behaviour, with higher determination coefficients being observed for the former relationship. Hence, total rainfall explains reasonably the generated runoff, mainly for bare soil and Palma barriers conditions. As shown, mulching efficiently protected soil surface, thus increasing infiltration rate, and enhancing soil water storage, as discussed by Montenegro et al. (2013). Moreover, Brasil et al. (2017) highlighted the role of Caatinga canopy in reducing rainfall drops kinetic energy and in increasing soil moisture. Even at a deciduous biome, McLaughlin et al. (2013) verified the benefit of natural vegetation cover for increasing infiltration and water storage at the unsaturated zone, and enhancing evapotranspiration.

According to the box plot in Fig. 8, the natural Caatinga cover was efficient on increasing soil water storage. Such result was also reported by Caloiero et al. (2016). Although the presence of native forest increases water consumption due to transpiration, it is also verified that near surface soil moisture increased in comparison to areas where vegetation was removed. 

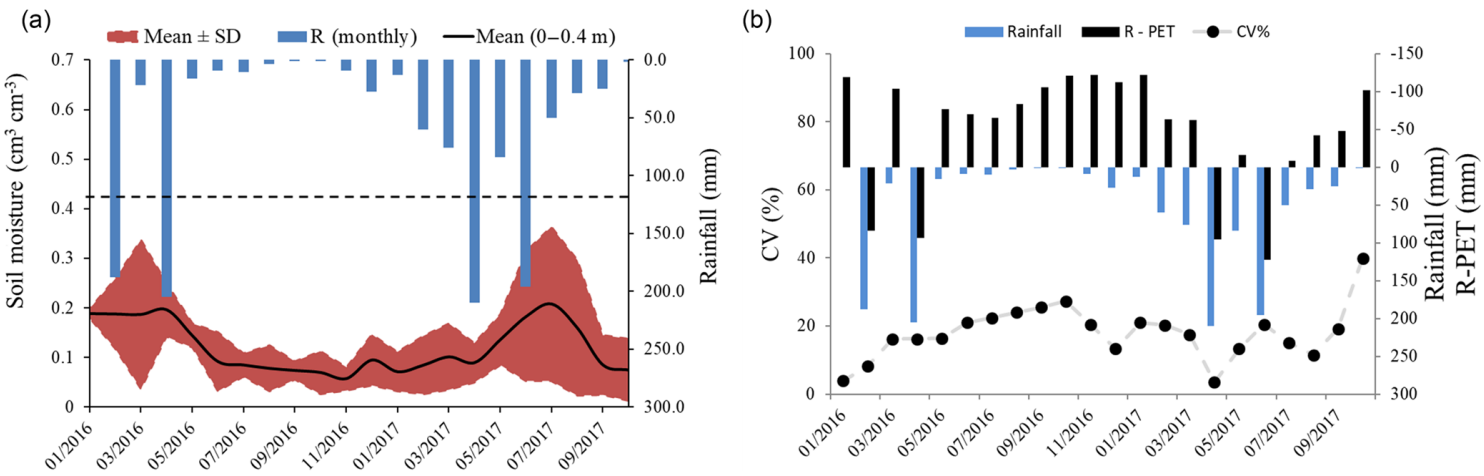

Figure 7. Monthly rainfall and mean soil moisture for the $0-0.40 \mathrm{~m}$ layer. One standard deviation interval around the mean value for the 0- $0.40 \mathrm{~m}$ layer, also showing the mean soil moisture at the field capacity (dashed line) (a); time series for the coefficient of variation of the mean soil moisture, and the net rainfall (R-ET) values (b).
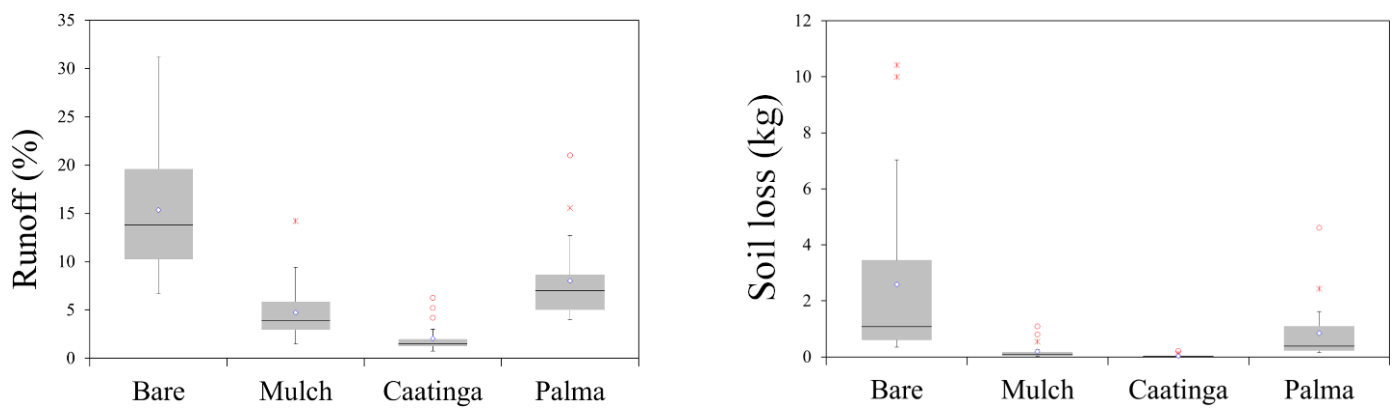

Figure 8. Box plots for runoff and soil loss, for native vegetation (Caatinga), Cactus barriers (Palma), mulching and bare soil, at the experimental plots, at site 1 , for the $0-0.20$ m layer.

\section{Conclusions}

The study successfully addressed the role of Caatinga natural cover and of conservation practices (mulching and Palma barriers) for soil and water conservation in a semiarid ephemeral basin, where evapotranspiration usually exceeds rainfall. Mulching cover was particularly effective for controlling soil moisture during the dry periods, contributing to rainfed agriculture in such areas. The following conclusions could be drawn from this study:

i. The Caatinga deciduous vegetation is highly effective in terms of soil and water conservation for both the dry and the wet season, resulting in a positive nexus between vegetation and water availability at the region. The highest soil moisture contents have been verified, as well as the lowest runoff and soil losses rates;

ii. The Cactus barriers and mulching were effective for soil moisture conservation and for runoff reduction;

iii. Nature-based solutions applying cactus barriers and mulching efficiently increase soil moisture, reducing runoff and soil losses, contributing to restore semiarid degraded areas; iv. In this extremely hot semiarid environment soil moisture spatial variability increased with rainfall events at the beginning of the rainy season, and then decreases, due to lateral fluxes. When the soil dries, lateral flows are reduced, and the coefficient of variation increases as the evapotranspiration exceeds rainfall.

Data availability. Data is partially part of the second author's ongoing PhD. Hence, full acess is not yet possible. Contact Abelardo Montenegro.

Author contributions. AM and TS were responsible for the conceptualisation of the field study. Thais Souza conducted the soil analysis. JL, AM and Iug Lopes carried out data interpretation and final review; AA, FL, IL, TA, HL, and HM were responsible for conducting the field measurements and laboratory analysis, data acquisition and analysis; AM and IL were also responsible for data analysis and interpretation and review, and for writing the original manuscript.

Competing interests. The authors declare that they have no conflict of interest. 

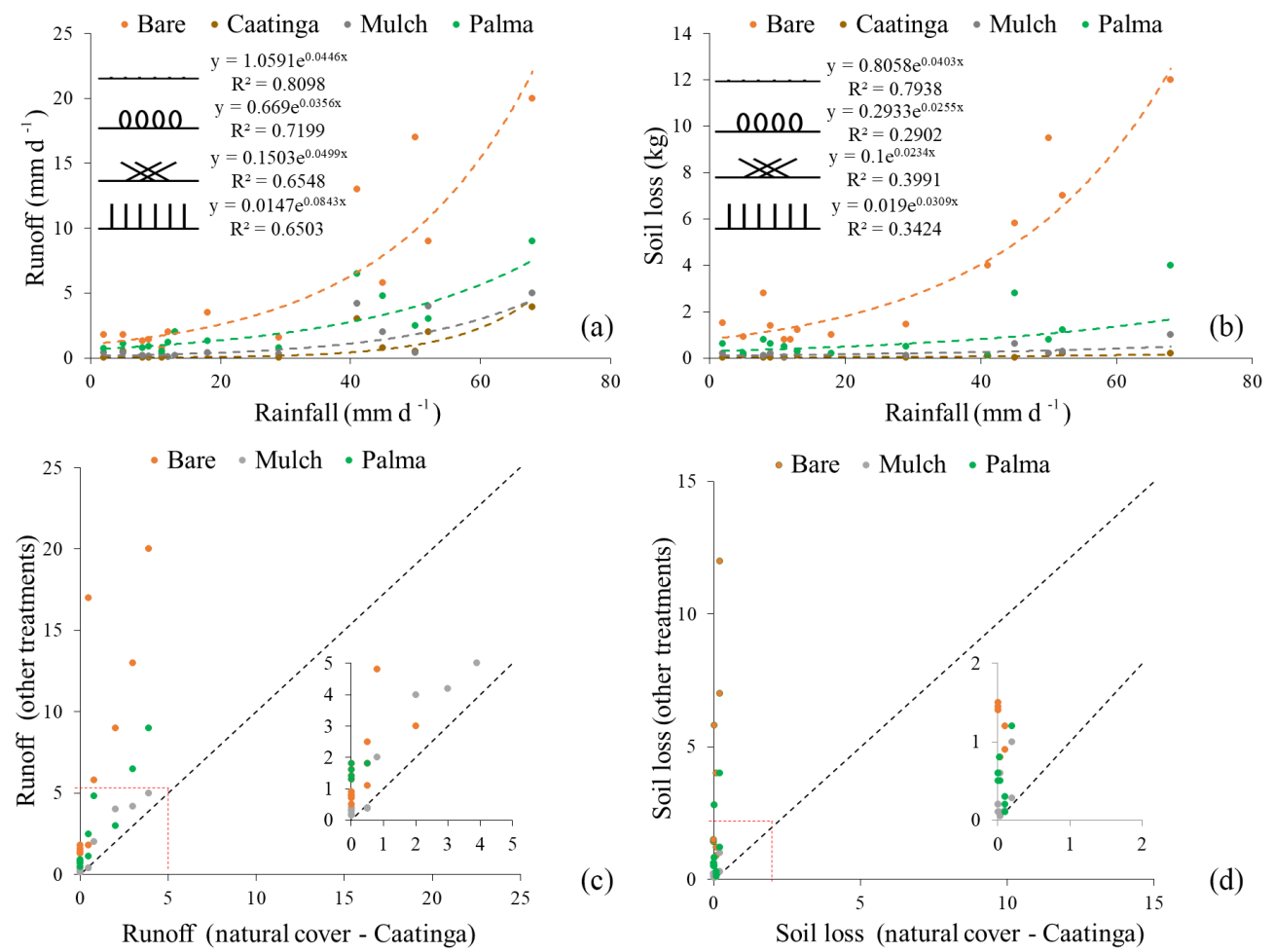

Figure 9. (a, b) Rainfall-runoff and rainfall-soil loss relationships for the different cover conditions. (c, d) Comparison of runoff and soil loss of different cover conditions with Caatinga.

Special issue statement. This article is part of the special issue "Innovative monitoring techniques and modelling approaches for analysing hydrological processes in small basins". It is a result of the 17th Biennial Conference ERB 2018, Darmstadt, Germany, 1114 September 2018.

Financial support. This research has been supported by the Foundation for Science and Technology of Pernambuco State (FACEPE) (grant nos. APQ 0300-5.03/17 (Universitas Consortium), APQ 0913-5.03/15 and Doctoral scholarship), by the National Council for Scientific and Technological Development (CNPq) (grant no. 420.488/2018-9 and grant no. 446254/2015-0) and by the Brazilian Innovation Agency (FINEP) (grant REHIDRO no. 1830/10 2010). To the financial support of Project HIRT-Modelling surface hydrologic processes based on infrared thermography at local and field scales (PTDC/ECM-HID/4259/2014 - POCI-01-0145FEDER-016668), from FCT, Portugal.

Review statement. This paper was edited by Britta Schmalz and reviewed by four anonymous referees.

\section{References}

Abrantes, J. R. C. B., Prats, S. A., Jacob, K., and de Lima, J. L. M. P.: Effectiveness of the application of rice straw mulching strips in reducing runoff and soil loss: Laboratory soil flume experiments under simulated rainfall, Soil Till. Res., 180, 238-249, doi.org/10.1016/j.still.2018.03.015, 2018.

Barbosa, M. L., Silva, T. G. F. D., Zolnier, S., Silva, S. M. S. E., Steidle Neto, A. J., Barbosa, M. L., Silva, T. G. F. D., Zolnier, S., Silva, S. M. S. E., and Steidle Neto, A. J.: The influence of cladode morphology on the canopy formation of forage cactus plants, Rev. Caatinga, 31, 180-190, https://doi.org/10.1590/1983-21252018v31n121rc, 2018.

Brasil, J. B., Palácio, H. A. D. Q., Araújo Neto, J. R. D., Ribeiro Filho, J. C., and Andrade, E. M. D.: Características das chuvas e interceptação vegetal no Bioma Caatinga, Irriga, 22, 560-574, 2017.

Caloiero, T., Biondo, C., Callegari, G., Collalti, A., Froio, R., Maesano, M., Matteucci, G., Pellicone G., and Veltri A.: Results of a long-term study on an experimental watershed in southern Italy, Forum Geografic, 15, 55-65, 2016.

Carvalho, A. A., Montenegro, A. A. A., Assis, F. M. C. V., Tabosa, J. N., Cavalcanti, R. Q., and Almeida, T. A. B.: Spatial dependence of attributes of rainfed maize under distinct soil cover conditions, Rev. Bras. Eng. Agr. Amb., 23, 33-39, https://doi.org/10.1590/1807-1929/agriambi.v23n1p3339, 2019.

de Borges, T. K. S., Montenegro, A. A. A., dos Santos, T. E. M., da Silva, D. D., and de Silva Junior, V. P. E.: Effect of conservation practices on soil moisture and maize (Zea mays L.) cropping in the semi-arid northeast of Brazil, Rev. Bras. Ciênc. Solo, 38, 1862-1873, https://doi.org/10.1590/S0100$06832014000600021,2014$. 
de Londe, L. R., Coutinho, M. P., Di Gregório, L. T., Santos, L. B. L., and Soriano, E.: Desastres relacionados à água no Brasil: perspectivas e recomendações, Ambiente \& Sociedade, 17, 133-152, https://doi.org/10.1590/18094422ASOC1082V1742014, 2014.

dos Santos, T. E. M., da Silva, D. D., and Montenegro, A. A. A.: Temporal variability of soil water content under different surface conditions in the semiarid region of the Pernambuco state, Rev. Bras. Ciênc. Solo, 34, 1733-1741, https://doi.org/10.1590/S0100-06832010000500025, 2010.

Dubeux, J. C. B., dos Santos, M. V. F., de Andrade Lira, M., dos Santos, D. C., Farias, I., Lima, L. E., and Ferreira, R. L. C.: Productivity of Opuntia ficus-indica (L.) Miller under different $\mathrm{N}$ and $\mathrm{P}$ fertilization and plant population in north-east Brazil, J. Arid Environ., 67, 357-372, https://doi.org/10.1016/j.jaridenv.2006.02.015, 2006.

EMBRAPA: Empresa Brasileira de Pesquisa Agropecuária, Centro Nacional de Pesquisa de Solos, Manual de Métodos de Análise de Solos, 2. ed, Rio de Janeiro, Embrapa, 1997.

Foley, J. A., DeFries, R., Asner, G. P., Barford, C., Bonan, G., Carpenter, S. R., Chapin, F. S., Coe, M. T., Daily, G. C., Gibbs, H. K., Helkowski, J. H., Holloway, T., Howard, E. A., Kucharik, C. J., Monfreda, C., Patz, J. A., Prentice, I. C., Ramankutty, N., and Snyder, P. K.: Global Consequences of Land Use, Science, 309, 570-574, https://doi.org/10.1126/science.1111772, 2005.

Grayson, R. B., Western, A. W., Chiew, F. H. S., and Bloschl, G.: Preferred states in spatial soil moisture patterns: Local and nonlocal controls, Water Resour. Res., 33, 2897-2908, https://doi.org/10.1029/97WR02174, 1997.

Krol, M. S., Jaeger, A., Bronstert, A., and Guntner, A.: Integrated modelling of climate, water, soil, agricultural and socioeconomic processes: a general introduction of the methodology and some exemplary results from the semi-arid north-east of Brazil, J. Hydrol., 328, 417-431, 2006.

Lopes, I. and Montenegro, A. A. A.: Hydrological processes simulation at plot scale using the SMAP model in the semiarid, Geama, 9, 42-58, 2017.

Lopes, I., Melo, J. M. M., Carvalho, A. A., Moura, G. B. A., and Leal, B. G.: Análise multivariada no estudo da variação do Índice de Aridez da Bahia e Pernambuco, Agrometeoros, 26, 93-102, 2018.

Lopes, I., Montenegro, A. A. A., and de Lima, J. L. M. P.: Performance of Conservation Techniques for Semiarid Environments: Field Observations with Caatinga, Mulch, and Cactus Forage Palma, Water, 11, 792-790, 2019.

McClain, M. E.: Balancing Water Resources Development and Environmental Sustainability in Africa: A Review of Recent Research Findings and Applications, Ambio, 42, 549-565, https://doi.org/10.1007/s13280-012-0359-1, 2013.

McLaughlin, D. L., Kaplan, D. A., and Cohen, M. J.: Managing Forests for Increased Regional Water Yield in the Southeastern U.S. Coastal Plain, J. Am. Water Resour. Assoc., 49, 953-965, 2013.

Maneta, M., Schnabel, S., and Jetten, V.: Continuous spatially distributed simulation of surfasse and subsurface hydrological processes in a small semiarid catchment, Hydrol. Process., 22, 2196-2214, https://doi.org/10.1002/hyp.6817, 2008.

Melo, R. O. and Montenegro, A. A. A.: Dinâmica temporal da umidade do solo em uma bacia hidrográfica no semiárido Pernam- bucano, Revista Brasileira de Recursos Hídricos, 20, 430-441, https://doi.org/10.21168/rbrh.v20n2.p430-441, 2015.

Menezes, J. A. L., Santos, T. E. M., Montenegro, A. A. A., and Silva, J. R. L.: Comportamento temporal da umidade do solo sob Caatinga e solo descoberto na Bacia Experimental do Jatobá, Pernambuco, Water Resources and Irrigation Management, 2, 45-51, 2013.

Montenegro, A. A. A. and Montenegro, S. M. G. L.: Variabilidade espacial de classes de textura, salinidade e condutividade hidráulica de solos em planície aluvial, Rev. Bras. Eng. Agr. Amb., 10, 30-37, 2006.

Montenegro, A. A. A. and Ragab, R.: Hydrological response of a Brazilian semi-arid catchment to different land use and climate change scenarios: a modelling study, Hydrol. Process., 24, 2705 2723, https://doi.org/10.1002/hyp.7825, 2010.

Montenegro, A. A. A., Abrantes, J. R. C. B., de Lima, J. L. M. P., Singh, V. P., and Santos, T. E. M.: Impact of Mulching on Soil and Water Dynamics under Intermittent Simulated Rainfall, Catena, 109, 139-149, https://doi.org/10.1016/j.catena.2013.03.018, 2013.

Montenegro, A. A. A., Souza, T. E. S. M., Souza, E. R., and Montenegro, S. M. G. L.: Temporal dynamics of soil moisture and rainfall erosivity in a tropical volcanic archipelago, J. Hydrol., 563, 737-749, 2018.

Mutti, P. R., da Silva, L. L., Medeiros, S. de S., Dubreuil, V., Mendes, K. R., Marques, T. V., Lúcio, P. S., Santos e Silva, C. M., and Bezerra, B. G.: Basin scale rainfallevapotranspiration dynamics in a tropical semiarid environment during dry and wet years, Int. J. Appl. Earth Obs., 75, 29-43, https://doi.org/10.1016/j.jag.2018.10.007, 2019.

Prats, S. A., Abrantes, J. R., Crema, I. P., Keizer, J. J., and de Lima, J. L. M. P.: Runoff and soil erosion mitigation with sieved forest residue mulch strips under controlled laboratory conditions, Forest Ecol. Manag., 396, 102-112, https://doi.org/10.1016/j.foreco.2017.04.019, 2017.

Santos, J. C. N., Andrade, E. M., Guerreiro, M. J. S., Medeiros, P. H. A., Palácio, H. A. Q., and Araújo Neto, J. R.: Effect of dry spells and soil cracking on runoff generation in a semiarid micro watershed under land use change, J. Hydrol., 541, 1-10, 2016.

Schneider, S., Shiki, S., and Belik, W.: Rural development in Brazil: overcoming inequalities and building new markets, Riv. Econ. Agr., 65, 225-259, 2010.

Silva, T. G. F., Primo, J. T. A., Morais, J. E. F., Diniz, W. J. S., Souza, C. A. A., and Silva, M. C.: Crescimento e produtividade de clones de palma forrageira no semiárido e relações com variáveis meteorológicas, Rev. Caatinga, 28, 10-18, 2015.

Silva Júnior, V. P., Montenegro, A. A. A., and Melo, R.: Temporal stability of soil moisture in a experimental watershed in the Pernambuco semi-arid region, Rev. Bras. Eng. Agr. Amb., 20, https://doi.org/10.1590/1807-1929/agriambi.v20n10p880-885, 2016.

Stuhler, J. and Orrock, J.: Historical land use and present-day canopy thinning differentially affect the distribution and abundance of invasive and native ant species, Biol. Invasions, 18, 1813-1825, https://doi.org/10.1007/s10530-016-1122-5, 2016.

Vachaud, G., Passerat de Silans, A., Balabanis, P., and Vauclin, M.: Temporal stability of spatially measured soil water probability density function, Soil Sci. Soc. Am. J., 49, 822-827, 
30 A. A. A. Montenegro et al.: Moisture Dynamics and Runoff under Different Cover Conditions in Semiarid Brazil

https://doi.org/10.2136/sssaj1985.03615995004900040006x, 1985.

Wenninger, J., Uhlenbrook, S., Lorentz, S., and Leibundgut, C.: Identification of runoff generation processes using combined hydrometric, tracer and geophysical methods in a headwater catchment in South Africa, Hydrol. Sci. J., 53, 65-80, 2008.
WWAP (United Nations World Water Assessment Programme)/UN-Water: The United Nations World Water Development Report 2018: Nature-Based Solutions for Water, Paris, UNESCO, 2018. 